\title{
Persepsi Pengusaha Mikro Terhadap Lembaga Keuangan Mikro \\ di Makassar
}

Oleh:

\section{H.M. Imam Taufiq HB./Rosnaini Daga}

Dosen STIM Nitro Makassar

\begin{abstract}
Abstrak
Berdasarkan UU No. 20 Tahun 2008 yang termasuk sebagai UMKM adalah usaha yang memenuhi kriteria sebagai berikut yaitu (1) memiliki kekayaan bersih paling banyak Rp50.000.000,00 (lima puluh juta rupiah) tidak termasuk tanah dan bangunan tempat usaha, atau (2) Memiliki hasil penjualan tahunan paling banyak Rp300.000.000,00 (tiga ratus juta rupiah).

Menurut Asian Development Bank (ADB), Lembaga Keuangan Mikro (microfinance) adalah lembaga yang menyediakan jasa penyimpanan (deposits), kredit (loans), pembayaran berbagai transaksi jasa (payment services) serta money transfers yang ditujukan bagi masyarakat miskin dan pengusaha kecil (insurance to poor and low-income households and their microenterprises). Sedangkan bentuk LKM dapat berupa: (1) lembaga formal misalnya bank desa dan koperasi, (2) lembaga semiformal misalnya organisasi non pemerintah, dan (3) sumber-sumber informal misalnya pelepas uang .
\end{abstract}

\section{Kata kunci : Pengusaha Mikro/ UMKM, Lembaga Keuangan Mikro \\ PENDAHULUAN}

Keberadaan Lembaga Keuangan Mikro (LKM) tidak terlepas dari perkembangan Usaha Mikro, Kecil dan Menengah (UMKM). Kinerja UMKM dalam beberapa tahun terakhir menunjukkan peningkatan. Data Badan Pusat Statistik (BPS) menunjukkan besaran Produk Domestik Bruto yang diciptakan UMKM dalam tahun 2003 mencapai nilai $\quad$ Rp 1.013,5 triliun (56,7 persen dari PDB).

Harian Upeks (18-3-2011), memuat bahwa 80\% pelaku UMKM di Sul-Sel belum tersentuh Kredit. Lembaga Pemberdayaan Usaha Mikro kecil dan Menengah Sulsel (LPUMKM) mencatat dari 700 ribu pelaku UMKM yang terdata, $80 \%$ atau sekitar 560 ribu diantaranya belum tersentuh kredit. Menurut Manager LPUMKM. Diperlukan sinergitas diantara pelaku UMKM dengan pihak Lembaga Keuangan yang memberikan kredit. Peran serta pelaku usaha mikro dalam meningkatkan pertumbuhan perekonomian di Sulsel merupakan ujung tombak 
dari pertumbuhan perekonomian dengan dibantu dari pemberian dana kredit yag disalurkan oleh lembaga keuangan Mikro. Pelaku usaha Mikro di SulSel terbilang sangat berkembang, dimana jumlah terbilang cukup besar yang mencapai sekitar 700 ribu pelaku usaha UMKM dan baru sekitar 20 persen pelaku UMKM yang mendapat bantuan kredit dari Lembaga Keuangan.(Harian Upeks)

\section{RUMUSAN MASALAH}

Adapun yang menjadi rumusan masalah dalam penelitian ini, yaitu : “ Bagaimana Persepsi pengusaha mikro terhadap pelayanan lembaga keuangan mikro khususnya di Makassar?".

\section{TINJAUAN PUSTAKA}

\section{Pengertian Lembaga Keuangan Mikro}

Lembaga Keuangan Mikro (LKM). Menurut Asian Development Bank (ADB), lembaga keuangan mikro (microfinance) adalah lembaga yang menyediakan jasa penyimpanan (deposits), kredit (loans), pembayaran berbagai transaksi jasa (payment services) serta money transfers yang ditujukan bagi masyarakat miskin dan pengusaha kecil (insurance to poor and low-income households and their microenterprises). Sedangkan bentuk LKM dapat berupa: (1) lembaga formal misalnya bank desa dan koperasi, (2) lembaga semiformal misalnya organisasi non pemerintah, dan (3) sumber-sumber informal misalnya pelepas uang.

\section{Pengertian Pelayanan}

Dikatakan terdapat keunggulan-keunggulan atas pelayanan yang diberikan oleh produsen dengan harapan mampu memenuhi keinginan dan kebutuhan konsumen.(berdasarkan Jurnal Manajemen dan Kewirausahaan, "Analisa Kualitas Pelayanan" volume 1, September 1999). Adapun kualitas pelayanan rneliputi sikap customer service, tanggapan terhadap keluhan konsumen, jasa pembayaran, fasilitas tambahan dan ketepatan waktu.

\section{Teori Perilaku Konsumen}

Perilaku konsumen adalah segala sesuatu yang mempengaruhi seseorang dalam memutuskan suatu hal, perilaku ini dipengaruhi oleh faktor-faktor yang bersifat internal dan ekstemal. Faktor internal adalah faktor yang timbul dari dalam konsumen itu sendiri yang meliputi usia konsumen, pekerjaan konsumen, keadaan ekonomi konsumen, gaya hidup seseorang, motivasi dalam menggunakan sesuatu, persepsi terhadap suatu produk, kepercayaan dan sikap konsumen terhadap produk yang dibeli. Sedangkan faktor ekstemal adatah faktor yang mendorong seseorang dari luar konsumen itu sendiri, yaitu kebudayaan 
seseorang, kelas sosial konsumen, faktor yang mempengaruhi diluar keluarganya yaitu referensi dari atasan atau teman.

\section{Teori Persepsi dan Harapan Konsumen}

Persepsi menurut Krehtner (2005:202-213) adalah proses interpretasi seseorang akan lingkungannya. Persepsi sosial meliputi empat tahap proses informasi, yaitu: Tahap pertama adalah perhatian yang selektif dan pemahaman. Tahap kedua adalah pengkodean dan penyederhanaan. Tahap ketiga adalah penyimpanan. dan Tahap keempat adalah tanggapan, penilaian dan keputusan.

Setiap konsumen pasti mempunyai harapan dalam membuat suatu keputusan pembelian. Harapan inilah yang mempunyai peran besar sebagai standar perbandingan dalam mengevaluasi kualitas maupun kepuasan konsumen.

\section{Pengertian Pengusaha Mikro dan Kriteria Pengusaha Mikro}

Pengusaha kecil / Pedagang kecil atau pengecer (Swastha 2005:192) adalah sebuah lembaga yang melakukan kegiatan usaha menjual barang kepada konsumen akhir untuk keperluan pribadi. Pedagang dapat dibedakan atas tiga macam (Wardani 2003:18) yaitu :

1. Pedagang besar, yaitu seseorang yang melaksanakan transaksi secara besar-besaran, artinya orang tersebut membeli barang dalam partai besar dan menjualnya kembali secara besar-besaran pula sehingga tidak melayani pembelian secara eceran. Termasuk dalam kelompok pedagang besar adalah grosir dan tengkulak.

2. Pedagang eceran, yaitu orang yang melakukan transaksi pembelian barang secara besar-besaran dan menjualnya kembali secara eceran/kecil-kecilan.

3. Pedagang kecil, yaitu orang yang melakukan kegiatan pembelian barang secara eceran/kecil-kecilan.

\section{KERANGKA PEMIKIRAN}

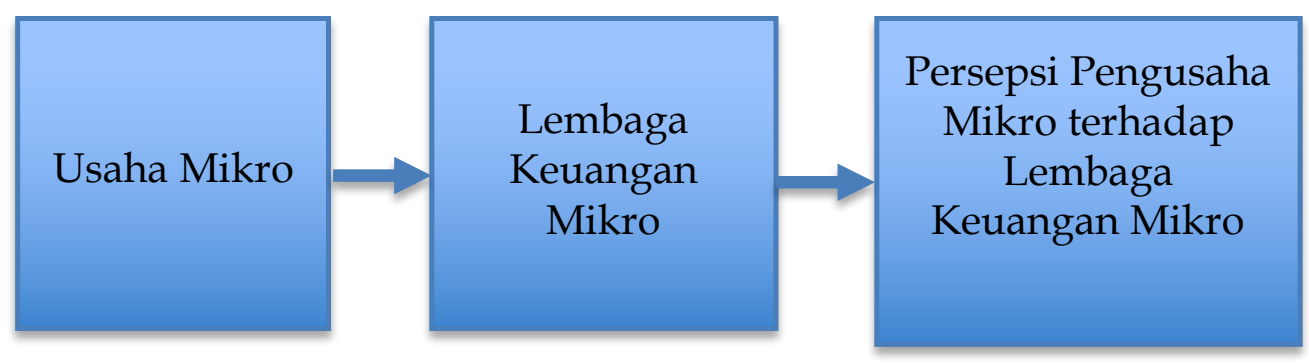

METODE PENELITIAN

\section{Metode Analisis Data}


Data primer yang telah diperoleh disortir untuk memilah data yang baik dengan data yang cacat. Data-data yang baik kemudian di tabulasi dengan menggunakan pembobotan skala Likert.

Alat analisis yang digunakan dalam penelitian ini adalah Analisis Deskriptif Kualitatif, alat analisis ini digunakan untuk mendeskripsikan hasil data dari variabel bebas yaitu Persepsi Pengusaha Mikro beserta indikatornya dan variabel terikat yaitu pembiayaan Lembaga Keuangan Mikro. Indikator-indikator tersebut yaitu : (1) Proses administrasi Kredit, (2) Persyaratan Kredit, (3) Survei, (4) Biaya administrasi, (5) Jaminan, (6) waktu kredit, (7) Harga / bunga.

\section{Validitas dan Reliabilitas}

Validitas (Arikunto 200:160 adalah suatu ukuran yang menunjukkan tingkat-tingkat kevalidan atau kesahihan suatu instrumen. Instrumen dikatakan valid apabila dapat mengungkapkan data dari variabel yang akan diteliti secara tepat. Suatu instrumen yang valid atau shahih mempunyai validitas yang tinggi, sebaliknya instrumen yang kurang valid mempunyai validitas yang rendah.

Reliabilitas menunjuk pada suatu pengertian bahwa sesuatu instrument cukup dapat dipercaya untuk digunakan sebagai alat pengumpul data karena instrumen tersebut sudah baik (Arikunto 2002:170). Reliabilitas sebagai alat ukur dimaksudkan untuk mengetahui sejauh mana kebenaran alat ukur tersebut sesuai atau cocok digunakan sebagai alat ukur.

\section{Defenisi Operasional}

Dengan demikian unsur-unsur yang terdapat dalam kredit yaitu:

1. Administrasi kredit, Yaitu proses administrasi mulai dari permohonan kredit sampai pada pencairan dana.

2. Persyaratan kredit, yaitu Persyaratan yang harus diserahkan oleh nasabah kepada lembaga keuangan yang member kredit, seperti Photo copy KTP suami Istri, Kartu Keluarga, Sertifikat jaminan.

3. Survey, yaitu Survey yang dilakukan oleh pemberi kredit terhadap calon nasabah yang akan diberikan kredit.

4. Biaya administrasi, yaitu biaya yang diberlakukan oleh lembaga keuangan terhadap nasabah yang mengambil kredit.

5. Jaminan, yaitu jaminan / agunan yang diserahkan oleh nasabah kepada lembaga keuangan.

6. Waktu, yaitu jangka waktu pembayaran kredit yang diberikan oleh lembaga keuangan kepada pihak nasabah.

7. Bunga, yaitu biaya bunga yang diberlakukan oleh pihak lembaga keuangan kepada nasabah yang mengambil kredit.

\section{HASIL PENELITIAN DAN PEMBAHASAN}

\section{Hasil Penelitian}


Sesuai dengan jawaban pada kuesioner dari 60 Responden pelaku usaha kecil dan menengah di Makassar, didapatkan hasil penelitian sebagai berikut :

\section{Pandangan Proses Administrasi Kredit}

Tabel 4.2.1. Persepsi Terhadap Proses Administrasi Kredit

\begin{tabular}{|l|c|c|c|}
\hline \multirow{2}{*}{ Jawaban } & \multicolumn{2}{|c|}{ Hasil } & \multirow{2}{*}{ Kategori } \\
\cline { 2 - 3 } & Responden & $(\%)$ & \\
\hline Sangat Baik & 10 & 16,6 & \multirow{2}{*}{ Baik } \\
\hline Baik & 29 & 48,3 & \\
\hline Cukup Baik & 16 & 26,6 & \multirow{2}{*}{ Tidak Baik } \\
\hline Tidak Baik & 4 & 6,6 & \\
\hline Sangat Tidak Baik & 1 & 1,6 & \\
\hline Jumlah & 60 & 100 & \\
\hline
\end{tabular}

Sumber: Data primer diolah, 2011

Berdasarkan tabel 4.2.1 di atas diperoleh hasil angka sebesar 55 responden atau $(91,7 \%)$ yang menyatakan Baik terhadap proses Administrasi pengambilan kredit dan sebanyak 5 responden atau $(8,3 \%)$ yang menyatakan Tidak baik terhadap proses Administrasi pengambilan Kredit pada Lembaga Keuangan Mikro.

2. Persyaratan Pengambilan Kredit Yang Ringan

Tabel 4.2.2 : Persepsi terhadap Persyaratan Pengambilan Kredit

\begin{tabular}{|l|c|c|c|}
\hline \multirow{2}{*}{ Jawaban } & \multicolumn{2}{|c|}{ Hasil } & \multirow{2}{*}{ Kategori } \\
\cline { 2 - 3 } & Responden & $(\%)$ & \\
\hline Sangat Baik & 9 & 15 & \multirow{2}{*}{ Baik } \\
\hline Baik & 21 & 35 & \\
\hline Cukup Baik & 28 & 46,7 & \multirow{2}{*}{ Tidak Baik } \\
\hline Tidak Baik & 1 & 1,6 & \\
\hline Sangat Tidak Baik & 1 & 1,6 & \\
\hline Jumlah & 60 & 100 & \\
\hline
\end{tabular}

Sumber: Data primer diolah, 2011

Tabel 4.2.2 di atas menunjukkan bahwa sebanyak 58 responden atau $(96,7 \%)$ yang menyatakan Baik terhadap persyaratan pengambilan kredit dan sebanyak 2 responden atau $(3,3 \%)$ yang menyatakan Tidak baik terhadap persyaratan yang ditetapkan oleh pada lembaga Keuangan Mikro di Makassar.

3. Survey terhadap Pengambilan Kredit

Tabel. 4.2.3. Persepsi Terhadap Survey Pengambilan Kredit

\begin{tabular}{|l|c|c|c|}
\hline \multirow{2}{*}{ Jawaban } & \multicolumn{2}{|c|}{ Hasil } & \multirow{2}{*}{ Kategori } \\
\cline { 2 - 3 } & Responden & $(\%)$ & \\
\hline Sangat Baik & 5 & 8,3 & \multirow{2}{*}{ Baik } \\
\hline Baik & 35 & 58,3 & \\
\hline Cukup Baik & 19 & 31,7 & \\
\hline
\end{tabular}




\begin{tabular}{|l|c|c|c|}
\hline Tidak Baik & 1 & 1,7 & \multirow{2}{*}{ Tidak Baik } \\
\hline Sangat Tidak Baik & 0 & 0 & \\
\hline Jumlah & 60 & 100 & \\
\hline
\end{tabular}

Sumber: Data primer diolah, 2011

Berdasarkan tabel 4.2.3 di atas, diketahui mayoritas responden yaitu sebesar 59 responden atau $(98,3 \%)$ menyatakan Baik terhadap dilakukannya Survey terhadap calon nasabah dan sebanyak 1 responden atau $(1,7 \%)$ yang menyatakan Tidak baik terhadap Survey yang dilakukan oleh petugas Lembaga Keuangan Mikro.

\section{Biaya Administrasi Pengambilan Kredit}

Tabel. 4.2.4. Persepsi Terhadap Biaya Administrasi

\begin{tabular}{|l|c|c|c|}
\hline \multirow{2}{*}{ Jawaban } & \multicolumn{2}{|c|}{ Hasil } & \multirow{2}{*}{ Kategori } \\
\cline { 2 - 3 } & Responden & $(\%)$ & \\
\hline Sangat Baik & 5 & 8,3 & \multirow{2}{*}{ Baik } \\
\hline Baik & 29 & 48,3 & \\
\hline Cukup Baik & 24 & 40 & \multirow{2}{*}{ Tidak Baik } \\
\hline Tidak Baik & 1 & 1,6 & \\
\hline Sangat Tidak Baik & 1 & 1,6 & \\
\hline Jumlah & 60 & 100 & \\
\hline
\end{tabular}

Sumber: Data primer diolah, 2011

Dari tabel 4.2.4 diatas diketahui sebagian besar responden yaitu 58 responden atau $(97,4 \%)$ menyatakan Baik terhadap biaya administrasi, dan 2 responden atau $(3,6 \%)$ yang memberikan penilaian Tidak baik terhadap biaya administrasi yang ditetapkan oleh pihak Lembaga Keuangan Mikro di Makassar.

5. Jaminan Pengambilan Kredit

Tabel 4.2.5. Persepsi Terhadap Jaminan Pengambilan Kredit

\begin{tabular}{|l|c|c|c|}
\hline \multirow{2}{*}{ Jawaban } & \multicolumn{2}{|c|}{ Hasil } & \multirow{2}{*}{ Kategori } \\
\cline { 2 - 3 } & Responden & $(\%)$ & \\
\hline Sangat Baik & 6 & 10 & \multirow{2}{*}{ Baik } \\
\hline Baik & 33 & 55 & \\
\hline Cukup Baik & 18 & 30 & \multirow{2}{*}{ Tidak Baik } \\
\hline Tidak Baik & 4 & 6,7 & \\
\hline Sangat Tidak Baik & 2 & 3,3 & 100 \\
\hline Jumlah & 60 & &
\end{tabular}

Sumber: Data primer diolah, 2011

Dari tebel 4.2.5 di atas dapat diketahui bahwa sebagian besar responden yaitu sebanyak 54 responden atau $(90, \%)$ yang memberikan penilaian Baik 
tehadap jaminan Kredit, dan sebanyak 6 responden atau (10\%) yang menyatakan Tidak Baik terhadap jaminan kredit yang diminta oleh pihak Lembaga Keuangan Mikro di Makassar.

6. Jangka Waktu Pembayaran Kredit

Tabel. 4.2.6. Persepsi Terhadap Jangka pembayaran kredit.

\begin{tabular}{|l|c|c|c|}
\hline \multirow{2}{*}{ Jawaban } & \multicolumn{2}{|c|}{ Hasil } & \multirow{2}{*}{ Kategori } \\
\cline { 2 - 3 } & Responden & $(\%)$ & \\
\hline Sangat Baik & 2 & 3,3 & \multirow{2}{*}{ Baik } \\
\hline Baik & 30 & 50 & \\
\hline Cukup Baik & 25 & 41,7 & \multirow{2}{*}{ Tidak Baik } \\
\hline Tidak Baik & 2 & 3,4 & \\
\hline Sangat Tidak Baik & 1 & 1,6 & \\
\hline Jumlah & 60 & 100 & \\
\hline
\end{tabular}

Sumber: Data primer diolah, 2011

Dari tabel 4.2.6 diatas dapat dilihat bahwa sebanyak 57 responden atau $(92,6 \%)$ yang menyatakan Baik terhadap Jangka waktu pembayaran Kredit, dan sebanyak 3 responden atau (5\%) menyatakan Tidak baik terhadap pilihan jangka waktu pembayaran yang diberikan oleh Lembaga Keuangan Mikro di Makassar.

7. Persepsi Responden Terhadap Bunga Kredit yang diberikan

Tabel. 4.2.7. Persepsi Terhadap Bunga Kredit.

\begin{tabular}{|l|c|c|c|}
\hline \multirow{2}{*}{ Jawaban } & \multicolumn{2}{|c|}{ Hasil } & \multirow{2}{*}{ Kategori } \\
\cline { 2 - 3 } & Responden & $(\%)$ & \\
\hline Sangat Baik & 4 & 6,7 & \multirow{2}{*}{ Baik } \\
\hline Baik & 28 & 46,6 & \\
\hline Cukup Baik & 24 & 40 & \multirow{2}{*}{ Tidak Baik } \\
\hline Tidak Baik & 4 & 6,7 & \\
\hline Sangat Tidak Baik & 0 & 0 & \\
\hline Jumlah & 60 & 100 & \\
\hline
\end{tabular}

Sumber: Data primer diolah, 2011

Dari tabel 4.2.7 diatas dapat dilihat bahwa sebanyak 56 responden atau (93,3\%) yang menyatakan Baik terhadap bunga Kredit yang diberikan oleh Lembaga Keuangan Mikro di Makassar, dan sebanyak 4 responden atau (6,7\%) menyatakan Tidak baik terhadap bunga yang diberikan oleh Lembaga Keuangan Mikro di Makassar.

\section{Pembahasan hasil penelitian}

Variabel Persepsi Pengusaha Mikro terhadap Lembaga Keuangan Mikro (X)

Variabel (X) Persepsi Pengusaha Mikro terhadap Lembaga Keuangan Mikro dengan menggunakan 7 indikator yaitu (1) Proses administrasi Kredit, (2) 
Persyaratan Kredit, (3) Survei, (4) Biaya administrasi, (5) Jaminan, (6) waktu kredit, (7) Harga / bunga. Sebagai Berikut :

\section{Pandangan Proses Administrasi Kredit}

Pada tabel 4.2.1 diperoleh hasil angka sebesar 55 responden atau (91,7\%) yang menyatakan Baik terhadap proses Administrasi pengambilan kredit pada Lembaga Keuangan Mikro di Makassar dari mulai permohonan sampai dengan pencairan dana tidak membutuhkan waktu yang lama. dan sebanyak 5 responden atau $(8,3 \%)$ yang menyatakan Tidak baik terhadap proses Administrasi pengambilan Kredit pada Lembaga Keuangan Mikro membutuhkan waktu yang lama.

\section{Persyaratan Pengambilan Kredit Yang Ringan}

Pada Tabel 4.2.2 menunjukkan bahwa sebanyak 58 responden atau (96,7\%) yang menyatakan Baik terhadap persyaratan pengambilan kredit yang ditetapkan oleh Lembaga Keuangan Mikro di Makassar seperti fotokopi KTP suami istri, Kartu keluarga, sertifikat jaminan atau BPKB tidak memberatkan responden. Sedangkan sebanyak 2 responden atau $(3,3 \%)$ yang menyatakan Tidak baik terhadap persyaratan yang ditetapkan oleh pada lembaga Keuangan Mikro di Makassar karena memberatkan responden.

\section{Survey terhadap Pengambilan Kredit}

Berdasarkan tabel 4.2.3, diketahui mayoritas responden yaitu sebesar 59 responden atau (98,3\%) menyatakan Baik terhadap dilakukannya Survey sebelum pencairan dana oleh petugas Lembaga Keuangan Mikro di Makassar, hal ini disebabkan calon debitur ingin memberikan informasi secara benar dan jelas mengenai usaha yang mereka jalankan dengan harapan pihak Lembaga Keuangan Mikro menyetujui permohonan Kredit yang mereka ajukan. Sedangkan sebanyak 1 responden atau $(1,7 \%)$ yang menyatakan Tidak baik terhadap Survey yang dilakukan oleh petugas Lembaga Keuangan Mikro .

4. Biaya Administrasi Pengambilan Kredit

Pada tabel 4.2.4 diketahui sebagian besar responden yaitu 58 responden atau $(97,4 \%)$ menyatakan Baik terhadap biaya administrasi yang ditetapkan oleh Lembaga Keuangan Mikro di Makassar dan tidak memberatkan responden dikarenakan biaya tersebut merupakan biaya yang sudah ditentukan oleh Lembaga Keuangan Mikro di Makassar dan wajib dibayar oleh calon debitu,r. Sedangkan sebanyak 2 responden atau $(3,6 \%)$ yang memberikan penilaian Tidak baik terhadap biaya administrasi yang ditetapkan oleh pihak Lembaga Keuangan Mikro di Makassar, hal ini disebabkan plafond pembiayaan yang diajukan ke Lembaga Keuangan Mikro di Makassar merupakan batas kebutuhan dana yang telah mereka anggarkan.

\section{Jaminan Pengambilan Kredit}


Pada tebel 4.2.5 dapat diketahui bahwa sebagian besar responden yaitu sebanyak 54 responden atau (90,\%) yang memberikan penilaian Baik tehadap jaminan Kredit yang diminta oleh pihak Lembaga Keuangan Mikro di Makassar tidak memberatkan dikarenakan hal ini merupakan salah satu kewajiban yang harus mereka penuhi, Sedangkan sebanyak 6 responden atau $(10 \%)$ yang menyatakan Tidak Baik terhadap jaminan yang diminta oleh pihak Lembaga Keuangan Mikro di Makassar.

\section{Jangka Waktu Pembayaran Kredit}

Pada tabel 4.2.6 dapat dilihat bahwa sebanyak 57 responden atau (92,6\%) yang menyatakan Baik terhadap Jangka waktu pembayaran Kredit dari harian, bulanan maupun jatuh tempo yang diberikan oleh Lembaga Keuangan Mikro di Makassar lebih menguntungkan usaha responden hal ini dikarenakan pendapatan mereka yang setiap harinya tidak selalu sama, sedangkan sebanyak 3 responden atau (5\%) menyatakan Tidak baik terhadap pilihan jangka waktu pembayaran yang diberikan oleh Lembaga Keuangan Mikro karena tidak menguntungkan usaha mereka atau memberatkan responden.

\section{Persepsi Responden Terhadap Bunga Kredit yang diberikan}

Pada tabel 4.2.7 dapat dilihat bahwa sebanyak 56 responden atau (93,3\%) yang menyatakan Baik terhadap bunga Kredit yang diberikan oleh Lembaga Keuangan Mikro di Makassar lebih rendah dan menguntungkan usaha responden. Sedangkan sebanyak 4 responden atau $(6,7 \%)$ menyatakan Tidak baik terhadap bunga yang diberikan oleh Lembaga Keuangan Mikro dan mengangggap tinggi.

Berdasarkan penelitian yang dilakukan pada Februari-Maret 2011 terhadap 60 Pengusaha Mikro Kecil dan Menengah di Makassar diketahui persepsi responden terhadap Lembaga Keuangan Mikro di Makassar, mengenai prosedur pembiayaan dari mulai permohonan sampai dengan pencairan dana tidak membutuhkan waktu yang lama hal ini dikarenakan salah satu dari tujuan Lembaga Keuangan Mikro meningkatkan taraf hidup masyarakat melalui peningkatan usahanya. Selain proses pencairan dana yang cepat kepada nasabah yang mengambil kredit persyaratan Administrasi juga tidak memberatkan nasabah. Melakukan survey kepada calon nasabah yang akan dibiayainya (mengambil kredit) karena survey merupakan bagian yang tidak dapat dipisahkan dari pembiayaan / Kredit, survey dilakukan dengan tujuan untuk mengetahui data mengenai nasabah dalam hal tempat tinggal nasabah, jenis usaha dan kemampuan pembayaran kewajiban yang dilakukan oleh nasabah. Selain prosedur pembiayaan / Kredit yang cepat dan pembiayaan tanpa jaminan, kebebasan responden dalam pilihan jangka waktu harian untuk pembayaran Kredit pada Lembaga Keuangan Mikro di Makassar. Hal ini dikarenakan pendapatan responden yang setiap harinya bervariasi. 


\section{PENUTUP}

\section{Kesimpulan}

Persepsi pengusaha Mikro, Kecil dan Menengah di Makassar terhadap Lembaga Keuangan Mikro di Makassar berdasarkan jawaban responden pada umumnya sudah baik, hal ini berarti indikator-indikator yang ada dalam kuesioner yang diberikan kepada responden atau pengusaha Mikro, Kecil dan Menengah di Makassar oleh Lembaga Keuangan Mikro di Makassar sudah memenuhi kebutuhan nasabah.

\section{Saran}

Adapun saran yang diberikan dalam penelitian ini adalah sebagai berikut:

1. Lembaga Keuangan Mikro di Makassar harus lebih giat lagi untuk mensosialisasikan produknya kepada masyarakat khususnya kepada Pengusaha Mikro, Kecil dan Menengah.

2. Pihak Lembaga Keuangan Mikro di Makassar agar kiranya memberikan bimbingan kepada pengusaha Mikro, Kecil dan Menengah di Makassar agar dapat memanfaatkan bantuan modal yang diberikan kepadanya.

\section{DAFTAR PUSTAKA}

Arikunto, Suharsimi. 2002. Prosedur Penelitian. Jakarta: Rineka Cipta.

Alimarwan Hanan, 2003,Seri Kebijakan Usaha Penjaminan Kredit dan Perkuatan Usaha KUKM, Kementrian Koperasi dan UKM, Jakarta.

Badan Pusat Statistik. 2002. Statistik UKM.

Harian upeks online (18-3-2011)

Iman Sugema, The Next Revolution, paper pada Diskusi Panel Microfinance Revolution: "Future Perspective for Indonesian Market", Jakarta, 7 Desember 2004.

Kotler,Philip. 2000. Manajemen Pemasaran. Terjemahan Hendra Teguh, Ronny A Rusli dan Benjamin Molan.Buku I . Prenhallindo: Jakarta.

Krethner, Robert \& Angelo Kinicki. 2005. Perilaku Organisasi. Jakarta: Salemba empat.

Swastha, Basu. 2001. Azas-Azas Marketing. Yogyakarta: Liberty.

Swasono, 2001, perekonomian Indonesia.

Udin Wiratno dan Wawan Dhewanto, Jurnal Manajemen, "Analisis Usaha Mikro, Kecil dan Menengah" 2006

UU No. 20 Tahun 2008, Tentang kriteria UMKM

Valerie A. Zeithaml and Mary Jo Bitner

Wardani, Tri. 2003. 'Pengaruh Pemanfataan Kredit Terhadap Tingkat Pendapatan Pedagang Kecil Di Kabupaten Temanggung'. Skripsi. Universitas Negeri Semarang.

www.kti.bisnis.com 